\title{
Article
}

\section{Echoes of Frantz Fanon in the place and space of an alternative black mental health centre}

Mckeown, Michael and Wainwright, John Peter

Available at http://clok.uclan.ac.uk/30559/

Mckeown, Michael ORCID: 0000-0003-0235-1923 and Wainwright, John Peter ORCID: 0000-0002-8190-0144 (2020) Echoes of Frantz Fanon in the place and space of an alternative black mental health centre. Critical and Radical Social Work, 8 (3). pp. 323-338. ISSN 2049-8608

It is advisable to refer to the publisher's version if you intend to cite from the work. http://dx.doi.org/10.1332/204986019x15724516823395

For more information about UCLan's research in this area go to http://www.uclan.ac.uk/researchgroups/ and search for <name of research Group>.

For information about Research generally at UCLan please go to http://www.uclan.ac.uk/research/

All outputs in CLoK are protected by Intellectual Property Rights law, including Copyright law. Copyright, IPR and Moral Rights for the works on this site are retained by the individual authors and/or other copyright owners. Terms and conditions for use of this material are defined in the policies page.

\section{CLoK}

Central Lancashire online Knowledge www.clok.uclan.ac.uk

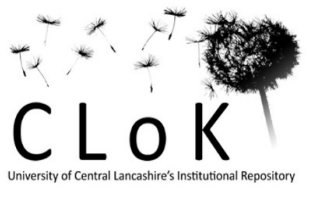




\section{Critical and Radical Social Work}

\section{Echoes of Frantz Fanon in the place and space of an alternative black mental health centre. \\ --Manuscript Draft--}

\begin{tabular}{|c|c|}
\hline Manuscript Number: & CRSW-D-19-00045R1 \\
\hline Article Type: & Academic article \\
\hline Full Title: & $\begin{array}{l}\text { Echoes of Frantz Fanon in the place and space of an alternative black mental health } \\
\text { centre. }\end{array}$ \\
\hline First Author: & Mick McKeown, PhD \\
\hline Corresponding Author: & $\begin{array}{l}\text { Mick McKeown, PhD } \\
\text { University of Central Lancashire } \\
\text { Preston, UNITED KINGDOM }\end{array}$ \\
\hline \multicolumn{2}{|l|}{$\begin{array}{l}\text { Corresponding Author Secondary } \\
\text { Information: }\end{array}$} \\
\hline Corresponding Author E-Mail: & mmckeown@uclan.ac.uk \\
\hline Other Authors: & John Wainwright \\
\hline \multicolumn{2}{|l|}{ Order of Authors Secondary Information: } \\
\hline Abstract: & $\begin{array}{l}\text { This paper draws on the published work of Frantz Fanon to engage critically with the } \\
\text { findings of a qualitative study of experiences within an alternative black mental health } \\
\text { centre in Liverpool. Fanon's critique of colonialism and exhortations for revolutionary } \\
\text { action chimes in with the activist beginnings of this centre, and the positive experiences } \\
\text { of service recipients are juxtaposed with previous negative experiences in the } \\
\text { mainstream mental health system. Notions of place and space are particularly } \\
\text { emphasised. These crucial variables were also arguably at the heart of Fanon's } \\
\text { critique of western psychiatry and its institutional failings. The relative neglect of Fanon } \\
\text { within psychiatry has arguably been to the detriment of the provision of appropriate } \\
\text { care and support for black communities in the UK. }\end{array}$ \\
\hline Keywords: & Frantz Fanon; psychiatry; mental health services; ethnicity; place. \\
\hline \multicolumn{2}{|l|}{ Additional Information: } \\
\hline Question & Response \\
\hline $\begin{array}{l}<\mathrm{b}>\text { Conflicts of Interest }</ \mathrm{b}></ \mathrm{br}> \\
\text { Please declare any possible conflicts of } \\
\text { interest, or state 'The Author(s) declare(s) } \\
\text { that there is no conflict of interest' if there } \\
\text { are none. Further information about } \\
\text { conflicts of interest can be found in our }<\mathrm{a} \\
\text { href="http://bristoluniversitypress.co.uk/as } \\
\text { set/6061/bup-and-pp-ethical-guidelines- } \\
\text { final.pdf" target="_blank" }>\text { Ethical } \\
\text { Guidelines. }\end{array}$ & None \\
\hline $\begin{array}{l}\text { Word Count } \\
\text { Academic articles should be between } \\
6000 \text { and } 8000 \text { words, including abstract, } \\
\text { notes, tables, figures and references. }\end{array}$ & 7342 \\
\hline Funding Information: & \\
\hline
\end{tabular}




\section{Echoes of Frantz Fanon in the place and space of an alternative black mental health centre.}

Mick McKeown ${ }^{1 *}$ and John Wainwright ${ }^{2}$,

*author for correspondence

Dr Mick McKeown, Professor of Democratic Mental Health, School of Nursing, University of Central Lancashire, Preston, UK, PR1 2HE

Email: mmckeown@uclan.ac.uk

1. School of Nursing, University of Central Lancashire, Preston, UK.

2. School of Social Work, Care and Community, University of Central Lancashire,

\section{Abstract}

This paper draws on the published work of Frantz Fanon to engage critically with the findings of a qualitative study of experiences within an alternative black mental health centre in Liverpool. Fanon's critique of colonialism and exhortations for revolutionary action chimes in with the activist beginnings of this centre, and the positive experiences of service recipients are juxtaposed with previous negative experiences in the mainstream mental health system. Notions of place and space are particularly emphasised. These crucial variables were also arguably at the heart of Fanon's critique of western psychiatry and its institutional failings. The relative neglect of Fanon within psychiatry has arguably been to the detriment of the provision of appropriate care and support for black communities in the UK.

Key words: Frantz Fanon, psychiatry, mental health services, ethnicity, place. 


\section{Echoes of Frantz Fanon in the place and space of an alternative black mental health centre.}

\section{Introduction}

For all the emphasis on empowerment in recent mental health policy and practice discourse for some time there has been precious little serious professional attention to understanding power, least of all dismantling iniquitous power structures and social relations (Hopton 1997, Cutcliffe \& Happell 2009). Conversely, more radical voices locate consideration of power as central to their ideas for reforming or transforming services, and, indeed, often link this to prescriptions for wider social change (see Sedgwick 1982). An intellectual giant, but a relatively neglected figure within the history of psychiatric practice, is Frantz Fanon, who is much better known for his trenchant critique of racism and politics for emancipation in the developing world (Zeilig 2016). In a telling critique of the perceived failings of so-called transcultural psychiatry, Kobena Mercer (1986) highlighted Fanon's political identification of power and domination, rather than cultural differences between doctors and patients, as the central issue in the creation of mental distress, and perpetuated by psychiatric oppression of colonial subjects.

Like the better known Che Guevara, Fanon was notably a doctor who devoted substantial efforts to revolutionary struggles. Unlike, Guevara, Fanon was also something of a revolutionary in his medical career, forging new, transformative ideas for psychiatry that were in tune with his broader politics (Khalfa 2016, Robertson and Walter 2009). Within Fanon's writings, entwined with an emphasis on race, there is a notable focus on the places he thought care and treatment should be delivered. Here we take up an interest in matters of race, place and space, weaving findings from a study within an alternative black mental health centre in Liverpool, Mary Seacole House (MSH), with reflections on Fanon's revolutionary perspective.

\section{Fanon the revolutionary, the psychiatrist, and the scholar}

Fanon was in the vanguard of contributions to the $20^{\text {th }}$ Century ideological and material challenge to colonialism (Zeilig 2016). Growing up in the French colony of Martinique he had personal knowledge of colonial racism and this was exacerbated in his time fighting for the allied forces in WWII, experiencing racism from both his commanders and liberated white communities, whereby black 
soldiers suffered multiple slights and exclusions. Later, he was to be involved in the care and

While he was alive, Fanon's intellectual powers were recognised and respected by some of the great thinkers of the age (Sartre 1963). In Black Skin, White Masks (BSWM), Fanon eloquently rages against racism, mixing cogent theorising with autobiography in a passionate refutation of the status quo and call for emancipation. In The Wretched of the Earth, which he raced to complete before he succumbed to leukaemia, his death hastened by an initial political refusal to seek treatment in the US, Fanon rails against narrow nationalisms and prophetically predicts the failings of many postcolonial regimes. For Fanon (1963: 203):

Nationalism is not a political doctrine, nor a programme ... a rapid step must be taken from national consciousness to political and social consciousness

\section{Fanon and critical psychiatry}

Fanon's writings on mental health care have typically received much less attention than his political oeuvre, yet these can reveal much about the development of his ideas as a whole, and definitely show him to have been 'committed to revolutionising mainstream psychiatric practice' (Khalfa 2018: 168). Coppock and Hopton (2002) point out the fact that some of the most insightful critique of psychiatry and understandings of mental distress have come from practitioners with personal experience of oppression; they include Fanon, and his experience of the Algerian independence struggles, in a list that also names Viktor Frankl and Bruno Bettleheim, psychoanalysts who endured Nazi concentration camps. 
With regard to timing, Fanon was developing his ideas about psychiatry at a time of significant geopolitical disturbances of the old world order, and his work in English translation began to emerge at exciting times for critique of the established psychiatric order. Fanon commenced by researching the limits of neuropsychiatric approaches, turning to adoption of sociotherapeutic developments (Fanon and Azoulay 1954), before focusing upon the importance of culture to mental health and distress (Khalfa 2018), predating more recent articulations of transcultural and culturally sensitive psychiatry by decades. Fanon's interest in the social aspects of therapy included creation of a patients' football team, involving the building of a football pitch at Blida asylum (Lacaton 1955/2018). Fanon was also ahead of his time in questioning the importance placed upon rules in institutional settings. Writing on this matter, Fanon (1956/2018: 348) stated: 'that formulating disciplinary rules and regulations at a psychiatric hospital is a therapeutic absurdity and that this idea must be abandoned once and for all'.

Fanon also brought innovation to the work of nurses and orderlies, taking a close interest in their training and practice. The effects were visible in the hospital atmosphere and work environment. Fanon established the tradition of a daily journal for any staff, visitor or patient to write in. One visitor from France, a Dr Gambs wrote:

\footnotetext{
A visitor used to psychiatric hospitals is less sensitive to the décor ... than he is to the atmosphere that prevails in it, and in your establishment that atmosphere struck me. No sterile restlessness, no throng of people around the doctor as he passed through the ward: each person is busy with his or her work and interested in it. Your nurses do not monitor you, but really 'live' among you, side by side, participating in the same activities as you. (Gambs 1955/2018: 331)
}

Fanon was particularly, and vehemently, opposed to the ethnocentricity of established western biopsychiatry. He was quick to realise that recreational and occupational opportunities within hospital spaces needed to be culturally appropriate otherwise they would have no appeal for residents. His concern with place would eventually lead him to experiment with day hospital models as a radical alternative to inpatient care (Fanon 1958/2018, Fanon and Geronimi 1959/2018) that 
were a substantial prefiguration of the future of mental health care, and arguably the blueprint for developments such as MSH in Liverpool in the 1990s.

\section{Fanon and the struggle for black emancipation}

Fanon's clinical and revolutionary work most obviously comes together in his seminal analysis of the damage inflicted upon the black psyche by being subject to colonial oppression. He theorised the revolutionary overthrow of colonialism and simultaneous freeing of previous colonial subjects of feelings of inferiority. For Fanon, the cumulative experience of being treated as inferior by the coloniser has an effect of poisoning one's sense of self, such that the colonised begin to internalise negative representations and can thus become complicit in their own oppression. The way out of this has to be efforts to raise consciousness, instil black pride, bolster identity, and improve selfesteem. Various critical commentators have highlighted how the aims of alternative black mental health services share this 'therapeutic' and social vision (Coppock and Hopton 2002); indeed, it is no accident that one such service in Brixton was named the Fanon Centre or that MSH in Liverpool is named after a similarly relatively neglected black pioneer; in this case of nursing.

In many respects, Fanon died a hero of the Algerian struggle for emancipation and, indeed, a hero for revolutionaries everywhere. Leo Zeilig (2016) in his moving and celebratory account of Fanon's life as a militant philosopher and revolutionary, describes how, despite his prestige, he lived in frugal simplicity. Deep into his terminal illness Fanon received visitors lying on a cot on the floor of a dwelling otherwise devoid of furniture and decoration, continuing to exhort passion for the revolutionary struggle and digest and critically discuss the latest scholarly outputs. Around this time, he famously visited the Algerian liberation forces at the front to explain his reading of Sartre's Critique de la Raison Dialectique, and impress on them his view that they needed to both win the armed struggle and ensure the proper, egalitarian, future of the subsequent nation. Zeilig (2016: 226) quotes Claude Lanzmann, a French leftist, who visited Fanon at this time in Tunis:

Fanon was lying on a sort of pallet, a mattress on the floor. I was immediately struck by his fiery dark eyes, black with fever ... I sat on the floor next to the mattress where Fanon lay and listened to him talk ... for hours, stopping several times when the pain became unbearable. I put my hand on his forehead, which was bathed in sweat, and awkwardly tried to dry it, or I 
held his shoulder gently as though by mere touch I might ease his pain. But all the while

\section{The contribution of Fanon's thought to contemporary critical discourse}

Critical mental health practitioners have long been drawn to Fanon's ideas. John Hopton (1995a), for example, highlighted the value of Fanon's thought for the practice of mental health nursing some three decades ago. In a wide ranging engagement with Fanon's work, Hopton (1995a) asserts that nurses inspired by Fanon should be politically active in resisting all forms of oppression and challenging disadvantage, working to develop alternative forms of mental health care within and in opposition to psychiatry. Hopton (1997), however, cautioned against naïve adoption of Fanon's ideas into contemporary fields and debates. As much as Fanon developed certain critical psychiatry ideas and practices, in many regards he was of his time, a traditional psychiatrist of the 1950s, and he was on balance more involved in anti-colonial politics than in transforming psychiatry.

That said, perhaps the most interesting dimension to Fanon's legacy was his interweaving of his revolutionary politics and his ideas for change in psychiatry. He was arguably one of the most radical of the era's critics of psychiatry, so it is regrettable that his writings are not as well known as other more visible commentators whose work was taken up in the so-called anti-psychiatry movement of the 1960s and 1970s. Fanon's commitment to both psychiatric and wider social change led him to position himself as an implicit critic of biological psychiatry by virtue of advancing aspects of a social model of mental health. For Fanon, there was clearly a complex interplay between biology/neurology and the socio-political context within which mental distress is formed. Hence, for Fanon it would be psycho-therapeutic to be involved in active resistance to political oppression. For critical commentators such as Coppock and Hopton (2002), Fanon's advancement of practical alternatives to both psychiatry and psychotherapy render him worthy of the adulation conferred on the more celebrated later anti-psychiatrists, whose work he prefigured in many respects. Similarly, given his work with survivors of war-time trauma and torture, perhaps Fanon deserves to be recognised as an early pioneer of trauma informed care yet he is seldom acknowledged as such.

A neglect of Fanon's work, especially his clinical writings, is not restricted to the mainstream. Coppock and Hopton (2002) also highlight this surprising absence in the writings of notable antipsychiatrist David Cooper, a commentator, like Fanon, steeped in existentialist and anti-capitalist 
theory. The relative lack of take up of Fanon's ideas has arguably left a Fanon shaped hole in the contemporary critical canon, yet echoes of his work continue to inform and shape critical and alternative perspectives and practices.

It is possible that Fanon's early death before the high water mark of anti-psychiatry was partly to blame for this neglect, but critique of Fanon's alleged affinity for violence may have also contributed. Gibson (2017) notes how Sartre's (1963) introduction to The Wretched of the Earth may have been partly responsible for mis-identifying Fanon as a glorifier of violence, whereas he actually saw violence as a problematic, albeit justified in the overthrow of tyrannical power (Martin 1970). Fanon's reflections on the therapeutic and emancipatory value of violent resistance to tyranny arguably connects well with more modern observations on the legitimacy of recalcitrance and violence on the part of psychiatric service user and survivor dissidents (Hopton 1995b, McKeown et al 2019). Penson (2014) advances critique of the colonising propensities of psychiatry, combining Fanonian and Foucauldian analyses to deepen appreciation of the value of post-colonial theorising for making sense of the power of psychiatry and the subjection of the mentally distressed within systems of psy-science.

Moreover, recent critique of psychiatry, including within the emergent field of mad studies and new anti-psychiatry, has arguably confirmed the importance of Fanon's work without necessarily referencing it thoroughly; exceptions include Colin King (2016). From this perspective, attention has been drawn to matters of epistemic injustice and violence ingrained within these systems (Russo \& Beresford 2015, Liegghio 2013). Critically minded practitioners have pointed out that, rather than being vexed by violence assumed to result from pathology or individual propensities, staff should reflect upon the violence that is ingrained into the very system they work in and sustain (Holmes et al. 2013). In many respects, this turn in critique of psychiatry harks back to Fanon, and could be strengthened and deepened with recourse to his theorising of race, given the anomalous treatment of ethnic minorities and indigenous peoples across global psychiatric systems. To some extent, this would require an accommodation of Fanon's ideas regarding colonial and revolutionary violence with other analyses that stress more symbolic forms (Von Holdt 2013).

Fanon's writings on homosexuality, however, have not dated at all well (Moore-Gilbert 1996, Goldie 2005), and feminists have both noted problems in his writing with relation to a progressive politics of 
gender (e.g. Decker 1990, Fuss 1995) and offered rebuttals (Sharpley-Whiting 1997, Dubey 1998). The degree of controversy regarding Fanon's work has a whole ought not detract from the salience of his anti-colonial critique for revolutionary movements and his connected psychiatric critique for the transformation of institutionalised care, especially, but not necessarily exclusively, with regard to race and rascism. Such a standpoint supports current re-visitation of the value of Fanon's ideas at the same time as acknowledging some of the more obvious shortcomings:

\begin{abstract}
If Fanon's legacy ... is to have any meaning for us today, it will be only insofar as we are able to apply his work - with all its insights and all of its limitations - to the pressing issues of contemporary cultural politics (Alessandrini 2005: 1).
\end{abstract}

\title{
The ongoing problematic relationship between race and psychiatry
}

Colonial regimes are not necessary for contemplation of an ongoing fractious relationship between psychiatry and race. Western psychiatric services are beset with various anomalies in care, treatment and outcomes for ethnic minorities which have been well documented and criticised in the UK, in relation to service provision (e.g. Care Quality Commission 2018) and the operation of mental health legislation (Department of Health and Social Care 2018). So-called new world nations are also noted for problematically over-representing indigenous peoples within their psychiatric systems (Gone 2007, Stowell-Smith \& McKeown 2001, Zubrick et al. 2004). Black men in particular, and ethnic minorities generally, find themselves subject to over-representation in most diagnostic categories, higher levels of compulsion, coercion, and seclusion, and receive higher doses of medication. They are disproportionately detained under the Mental Health Act, at higher levels of security, and processed into services via the courts or police. Moreover, ethnic minorities are less likely to be offered talking therapies or receive support or treatment in primary care settings (Bhui et al. 2015, Gajwani et al. 2016, Morgan et al. 2004, Raleigh et al. 2000).

Notwithstanding a plethora of policy targeting these problems and forged in the heat of a reaction to notable examples of societal and institutional racism ( $\mathrm{DoH}, 2005)$, including high profile deaths of black men detained in the mental health system (DoHSC, 2018), black communities continue to experience barriers to making themselves heard. This has not necessarily improved within more recent policy turns explicitly concerned with autonomy, user voice and recovery. Indeed, service 
user and survivor groups has also been criticised for deficits of representation with regard to ethnicity (Wallcraft, Read and Sweeney 2003).

Responding to the identified problems in mainstream mental health services, communities fell back upon their own resourcefulness, creating initiatives such as the Black Spaces Project to better support black service users and advocate for them and their communities (BME Voices, 2018; Christie and Hill, 2003; Wright and Hutnik, 2004). Various self-organised alternative services were developed in UK cities, including innovations at Bradford, Hackney, Brixton, Liverpool and Manchester (Francis, 1991; Fernando, 200; Christie and Hill 2003). The national mental health charity, MIND, arguably a more radical incarnation in those days, produced the magazine Diverse Minds, celebrating these alternatives and highlighting racial disadvantages elsewhere in the system. Over the years, however, these culturally sensitive safe havens have been challenged by the twofold threat of squeezed finances and resisting co-option into the mainstream services they must relate to. It is hard not to conclude that these threats have contributed to a relative lack of consensus on what counts as optimum provision in this field of culturally appropriate care and support (Littlewood \& Lipsedge 1997, Fernando 2005). The UK government health policy, Delivering Race Equality, was prompted by the most egregious of the noted anomalies of care, notably the death of a black service user, Rocky Bennett, in an incident infused with racism (NIMHE, 2003; DoH, 2005). The DRE approach utilised community development approach, employing community development workers across the country to assist in developing new and effective practices. Critics, however, have asserted that the aim of changing attitudes and practices within mainstream services was a diversion from securing the necessary resources to galvanise alternative services within communities (Fernando, 2010; Bhui et al. 2012).

\section{MSH and Liverpool 8: a short history of struggle and identity}

This paper pivots on analysis of people's experiences within Mary Seacole 2, House, an alternative mental health centre in Liverpool, founded in the 1990s, and entangled with wider struggles within the city centred on race. In a city notably racially segregated in terms of residence and employment opportunities, the majority of Liverpool's long-established black community live in Liverpool 8, known locally as Toxteth; comprising the Abercromby and Granby electoral wards. The city has a unique racialized constellation of social, economic, historical and geographic relations (Law and Henfry, 1981; Ben-Tovim, et al.1986; Liverpool Black Caucus, 1986; Small 1991) that have been 
influential in determining patterns of health and mental health disadvantage (Torkington 1991).

Residents of Liverpool as a whole claim a distinct 'scouse' identity, grounded in social and spatial imaginings, typically associated within the city with positive attributes of edgy exceptionalism and humour but also with externally generated negative connotations of disadvantage or criminality (Boland 2008a, 2008b). This 'scouseness' has a working class character that converts readily into an admixture of civic pride and rebelliousness. The latter has historically led to a propensity for militant reaction and resistance to assumed slights and injustices, such as those perceived to flow from the behaviour of government or employers (see Beynon, 1984; Taaffe and Mulhearn 1988). Arguably, the residents of Liverpool 8 are situated in ambivalent relationship to the scouse identity, being firmly of the city but also in many ways alienated from it.

In the vanguard of the struggle to establish Granby Community Mental Health Group, and thence Mary Seacole House, were three black women; Protasia Torkington, Yvonne Asige-Rooney and Leonie Nash. As such, as well as signifying a tangible legacy for the community efforts and activism that brought it into being, the very existence of this place exemplifies, by contrast, a challenge to the extant anomalies in the mainstream mental health system (GCMHG 2018; Gifford, Brown and Bundy 1989). In 1984 community activists, including Liverpool Black Sisters, targeted the local council, health authority and mental health officials with a campaign highlighting the racism experienced by black mental health system survivors. The Granby Community Mental Health Group (GCMHG) took shape following the establishment of an action research project focused on heath and race which provided evidence of discriminatory treatment. Subsequent dialogue with the local authority made the case for alternative provision more suited to the needs of the local black community (Torkington 1991, Torkington/GCMHG 2009). The consensus at the time was for 'drop in' and respite facilities in the Liverpool 8 area, that was to become MSH:

Where black people could feel free to discuss their personal anxieties, problems and crises in an unstructured and non-judgemental atmosphere, a space where they could safely express 
their frustration and anger about the racism they experience in all aspects of their lives.

Eventually, MSH, grew to offer a range of advice and consultancy and much needed health and wellbeing support in the community for individuals and their families and carers, alongside a bespoke Advocacy Project; one of the first of its kind in the country. The location of MSH, in an old Georgian building a stone's throw from the epicentre of significant riots in 1981, has considerable pyschogeographical connotations for the local people, especially the black community (Christian, 2008; Boland, 2010) and black psychiatric survivors (Torkington/GCMHG, 2009). The riots to a certain extent were a violent response to institutional racism in the local State, including aspects of economic and political marginalisation of Liverpool's black community, but perhaps more importantly represented a reaction to oppressive policing, especially of black young people (see ZakWilliams 1997, Christian 2008, Boland 2010). The relevant context, thus, resonates with ongoing and historical struggles against racism, particularly oppressions within the mainstream mental health system. The establishment of MSH in this context represents an attempt at re-assertion of control over community mental health, collectively damaged over the years by cycles of accumulated racisms (Torkington, 1991; Torkington/GCMHG, 2009; Gajwani et al. 2016, Singh et al. 2007). Situating the establishment and continuation of MSH within ongoing political struggles resonates somewhat with Fanon's observations on anti-colonial struggles, and the need to continue the struggle for equal social relations beyond any immediate victory or wresting of power from the coloniser. Thus, MSH is engaged in a continuing struggle for survival, both with regard to its material existence but also in terms of the clash of ideologies between alternative forms and the psychiatric mainstream and its situation within broader local struggles regarding race. Presently, with austerity driven denuding of the local voluntary sector, MSH is now the only black welfare agency in Liverpool (GCMHG, 2018). We describe the local context and how this has fed into the struggles to establish and maintain MSH in greater detail elsewhere (Wainwright \& McKeown, 2019).

\section{MSH and the saliency of place and space}

In the course of a participatory action research study we canvassed the views of members on their experiences of attending MSH and subject these to thematic analysis (Braun and Clarke 2006). We discuss the findings in more detail in a companion paper (Wainwright et al. 2019). Here we discuss a summary of the findings, with the key themes presented in Table 1. The importance of this study is 
that Fanon's work provides an opportunity to understand the work and experiences of those in MSH. and recognition, bound up with affinities for place and space in an environment sensitive to the oppressive experiences of mental health and race.

[insert Table 1 here]

Connecting all of these themes are issues at the intersection of matters of race, place and space that are not far removed from various of Fanon's critical concerns. Health and mental health outcomes have been noted to vary in relation to place, associated with intersections of ethnicity and disadvantage. Positive aspects of identity are linked to affinities for particular places (Proshansky et al. 1983, Low and Altman 1992) and this can lead to better mental health, mediating some of the adverse impact of the environment (Becares and Nazroo, 2013; Marcheshci et al., 2015). Conversely, antipathy towards place can result in worsened health outcomes (Stokols and Shumaker 1982) or strong attachments to place can result in exclusionary dispositions towards people perceived as different or outsiders (Fried 2000).

In the mental health services context, mainstream institutional places are perceived by black communities in the light of discrepant experiences of diagnosis and treatment, and, in a vicious cycle of mistrust, pathways into services for ethnic minorities become increasingly adverse. Alternative, self-organised, community located alternatives, such as MSH, offer different, more appreciated care, but there is a relative lack of evidence for this value. Our study provides qualitative evidence that demonstrates how this appreciation is strongly associated with place affinities and positive experiences within a safe physical and relational space, viewed contrastively with previous negative experiences of the mainstream and certain community exclusions. Taken together, this shows the imperative of considering the saliency of notions of place and space for considerations of the value of alternative support and advocacy services.

In this regard, Fanon's early criticisms of the institutional places of psychiatric care and the importance of locating ethnically appropriate support in community day centres remains acutely insightful and apposite. This shines through in the expressed affinities of the MSH members, intertwining attachments to both Liverpool 8 and MSH in their positive appreciation of the support and care received. The sense of emotional security and belonging engendered within the safe haven of the MSH space flows from this but is also strongly associated with matters of recognition and 
familiarity within this space, in contrast to experiences of racist exclusions elsewhere. In this regard

\section{What next: A Fanonian future?}

Ultimately, perhaps the most profound legacy of Fanon's ideas might be a re-commitment, in these austere times and beyond, to alternative, community located, culturally appropriate and unashamedly politically informed mental health services such as Mary Seacole House. Moreover, the emancipatory struggles to achieve the same may result in reinvigorations of culture, identities and social practices (see Gibson 2017) at stake in the enactment of consensual community mental health care and support. The relative neglect of Fanon's ideas could be remedied by efforts to include these more thoroughly within professional education curricula and the self-organised learning of survivor groups.

Fanon's work in many ways resonates with the struggles against racism of the local black community in Liverpool alongside the experiences of people of colour that experience mental distress and attend $\mathrm{MSH}$. The depiction of post colonialism in BSWM where Fanon himself is observed as a figure of curiosity, fun, and simultaneously fear by a white French child, embodies in many ways the experiences of black scousers, people of African heritage, when they venture outside the invisible 'boundaries' of Liverpool 8 (Zak Williams, 1997). It is a commonplace experience for black people to experience psychological and physical exclusionary and hostile behaviour. This may manifest itself, 
for instance, by security guards following them around a shop with the unspoken assumption that

Yet, it is Fanon's call to arms against colonialism and by implication psychiatry as a tool of Western power that is illuminated by MSH members' experiences. As black people that have at times experienced mental distress, who reside in the place of Liverpool 8, and feel most supported in the building and with the staff of MSH, rebellion and challenge can often be their raison d'etre (Torkington 1991; Torkington/GCMHG 2009). The community of Liverpool 8, in particular MSH, have had no choice but to challenge forces of racism that have pathologised them collectively and as individuals (Torkington, 1991; Zak Williams 1997). Fanon's exhortation to rip up western postcolonial notions of racial superiority and psychiatric pathology are taken up by MSH staff and members through their ethos and actions. Through a consistent challenge to local power structures in the city, and the mental health authorities, and providing an alternative world view for black members to identify with, MSH provides a narrative, a vision and an experience of post Fanonian hope. 
1

2

3

4

5

6

7

8

9

10

11

12

13

14

15

16

17

18

19

20

21

22

23

24

25

26

27

28

29

30

31

32

33

34

35

36

37

38

39

40

41

42

43

44

45

46

47

48

49

50

51

52

53

54

55

56

57

58

59

60

61

62

63

64

65

The Authors declare that there is no conflict of interest.

This research was not in receipt of grant funding. 


\section{References}

Alessandrini, A.C. (2005) Introduction. Fanon studies, cultural studies, cultural politics. In A.C. Alessandrini (ed.) Frantz Fanon: Critical Perspectives. London, Routledge. pp. 1-18.

Becares, L. \& Nazroo, J. (2013). Social capital, ethnic density and mental health among ethnic minority people in England: a mixed-methods study. Ethnicity \& Health, 18, 544-562.

Beynon, H. (1984). Working for Ford. Harmondsworth: Penguin.

Bhui, K., Ullrich, S., Kallis, C. \& Coid, J.W. (2015) Criminal justice pathways to psychiatric care for psychosis. The British Journal of Psychiatry, 207(6), 523-529.

Boland, P. (2008a). "Capital of Culture - you must be having a laugh" Challenging the official rhetoric of Liverpool as the 2008 European cultural capital. Social and Cultural Geography, 11(7), 627-645.

Boland, P.(2008b). The construction of images of people and place: Labelling Liverpool and stereotyping Scousers. Cities, 25, 355-369.

Boland, P. (2010). Sonic geography, place and race in the formation of local identity: Liverpool and Scousers. Geografiska Annaler: Series B, Human Geography, 92(1), 1-22.

Braun, V. \& Clarke, V. (2006). Using thematic analysis in psychology. Qualitative Research in Psychology, 3(2), 77-101. DOI: 10.1191/1478088706qp063oa

Care Quality Commission (2018). Monitoring the Mental Health Act: 2016 to 2017. The eighth annual report by the Care Quality Commission on the use of the Mental Health Act 1983. Newcastle: CQC.

Christian, M. (2008). The Fletcher report 1930: a historical case study of contested black mixed heritage Britishness. Journal of History and Sociolology Vol 21 No 2/3. pp 213-241

Christie Y. \& Hill N. (2003). Black Spaces Project. London: The Mental Health Foundation.

Coppock, V. and Hopton, J. (2002) Critical perspectives on mental health. London, Routledge.

Cutcliffe, J. and Happell, B. (2009) Psychiatry, mental health nurses, and invisible power: Exploring a perturbed relationship within contemporary mental health care. International Journal of Mental Health Nursing, 18(2), 116-125. 
Decker, J.L. (1990) Terrorism (un) veiled: Frantz Fanon and the women of Algiers. Cultural Critique, (17), 177-195.

Department of Health (2005). Delivering race equality in mental health care: an action plan for reform inside and outside services, and; The government's response to the independent inquiry into the death of David Bennett. London: Department of Health.

Department of Health and Social Care (2018). Modernising the Mental Health Act - final report from the independent review. London: DHSC.

Dubey, M. (1998) The" true lie" of the nation: Fanon and feminism. Differences: A Journal of Feminist Cultural Studies, 10(2), 1-3.

Fanon (1956) Editorials of the weekly ward journal of the Blida-Joinville psychiatric hospital, December 1953-December 1956. In J. Khalfa \& R. Young (eds) S. Corcoran (trns) Frantz Fanon: Alienation and freedom. London: Bloomsbury Publishing. 2018 pp. 311-348.

Fanon, F. (1959) Day hospitalisation in psychiatry: value and limits. La Tunisie Medicale, 37, 10, $713-$ 732. In J. Khalfa \& R. Young (eds) S. Corcoran (trns) Frantz Fanon: Alienation and freedom. London: Bloomsbury Publishing. 2018 pp. 495-509.

Fanon, F. (1967) Black skin, white masks. (Trns C. Markmann) New York: Grove Books.

Fanon, F. (1963) The wretched of the earth. (Trns C. Farrington) New York: Grove Books.

Fanon, F. and Geronimi, C. (1959) Day hospitalisation in psychiatry: value and limits Part Two: doctrinal considerations. La Tunisie Medicale, 37, 10, 689-712. In J. Khalfa \& R. Young (eds) S. Corcoran (trns) Frantz Fanon: Alienation and freedom. London: Bloomsbury Publishing. 2018 pp. 473-494.

Fanon, F. and Azoulay, J. (1954) Social therapy in a ward of Muslim men: methodological difficulties. L'Information Psychiatrique, 30, 9, 349-361. In J. Khalfa \& R. Young (eds) S. Corcoran (trns) Frantz Fanon: Alienation and freedom. London: Bloomsbury Publishing. 2018 pp. 330-331.

Fernando, S. (2005) Multicultural mental health services: projects for minority ethnic communities in England. Transcultural psychiatry, 42(3), 420-436.

Fernando, S. (2010) Mental health, race and culture. Macmillan International Higher Education. Francis E. (1991). Racism and Mental Health. Some causes for concern for Social Work.' Chapter 10 in Setting the Context for Change. Leeds: CCETSW 
Fried, M. (2000). Continuities and discontinuities of place. Journal of Environmental Psychology, 20(3), 193-205.

Fuss, D. (1995) Identification Papers. New York: Routledge.

Gajwani, R., Parsons, H., Birchwood, M. \& Singh, S.P. (2016). Ethnicity and detention: are Black and minority ethnic (BAME) groups disproportionately detained under the Mental Health Act 2007? Social Psychiatry and Psychiatric Epidemiology, 51(5), 703-711. https://doi.org/10.1007/s00127-016$1181-z$

[Doctor] Gambs. (1955) Regarding a visit. Our Journal (the weekly ward journal of the Blida-Joinville psychiatric hospital). In J. Khalfa \& R. Young (eds) S. Corcoran (trns) Frantz Fanon: Alienation and freedom. London: Bloomsbury Publishing. 2018 pp. 473-494.

GCMHG (2018). Annual Report 2017/18. Liverpool: Mary Seacole House.

Gibson, N.C. (2017) Fanon: The postcolonial imagination. Oxford, John Wiley \& Sons.

Gifford, A. M., Brown W., Bundy R. (1989). Loosen the Shackles. London: Karia Press.

Goldie, T. (2005) Saint Fanon and "homosexual territory". In In A.C. Alessandrini (ed.) Frantz Fanon: Critical Perspectives. London, Routledge. 87-98.

Gone, J.P. (2007) "We never was happy living like a Whiteman": Mental health disparities and the postcolonial predicament in American Indian communities. American journal of community psychology, 40(3-4), 290-300.

Hall, S. (1992). New Ethnicities. In 'Race' Culture and Difference (pp. 252-259). London: Sage.

Hall, S. (1996). Introduction: Who Needs Identity. In S. Hall, \& P. du Gay (Eds.), Questions of Cultural Identity (pp. 1-17). London: Sage.

Hall, S. (1998). Cultural identity and diaspora. in Rutherford, J. (ed.) Identity: community, culture, difference. 2nd edn. London: Lawrence and Wishart. pp. 222-237

Holmes, D., Rudge, T., Perron, A. and St. Pierre, I. (2013) Introduction: (Re)thinking violence in health care settings. In A. Perron, T. Rudge, and D. Holmes (eds.) (Re) Thinking Violence in Health Care Settings: A Critical Approach. Farnham, Ashgate Publishing.

Hopton, J. (1995a) The application of the ideas of Frantz Fanon to the practice of mental health nursing. Journal of Advanced Nursing, 21(4), 723-728. 
Hopton, J. (1995b) Control and restraint in contemporary psychiatric nursing: some ethical considerations. Journal of Advanced Nursing, 22(1), 110-115.

Hopton, J. (1997) Towards a critical theory of mental health nursing. Journal of Advanced Nursing, 25(3), 492-500.

Khalfa, K. (2018) Fanon, revolutionary psychiatrist. In J. Khalfa \& R. Young (eds) S. Corcoran (trns) Frantz Fanon: Alienation and freedom. London: Bloomsbury Publishing. pp. 167-202.

King, C. (2016) Whiteness in psychiatry: The madness of European misdiagnoses. In J. Russo and A. Sweeney (Eds) Searching for a Rose Garden. Weyastone Leys: PCCS Books, pp.85-92.

Lacaton, R. (1955/2018) Our Journal. Second year, Number 16. In J. Khalfa \& R. Young (eds) S. Corcoran (trns) Frantz Fanon: Alienation and freedom. London: Bloomsbury Publishing. pp. 333-334. Lashua, B. (2015). Mapping the politics of 'race', place and memory in Liverpool's popular music heritage. In S. Cohen, R. Knifton, M. Leonard \& L. Roberts (eds) Sites of popular music heritage: memories, histories, places. New York: Routledge. pp. 45-61.

Law, I. \& Henfrey, J. (1981). A history of race and racism in Liverpool, 1660-1950. Liverpool: Merseyside Community Relations Council.

Liegghio, M. (2013) A Denial of Being: Psychiatrization as Epistemic Violence. In B. Lefrançois, R. Menzies, and G. Reaume (eds) Mad Matters: A Critical Reader in Canadian Mad Studies. Toronto: Canadian Scholars Press.

Liverpool Black Caucus (1986). The racial politics of Militant in Liverpool: the black community's struggle for participation in local politics 1980-1986. Liverpool: Merseyside Area Profile Group and Runnymede Trust.

Littlewood, R. and Lipsedge, M. (1997) Aliens and alienists: ethnic minorities and psychiatry. London, Routledge.

Low, S. M. \& Altman, I. (1992). Place attachment: A conceptual inquiry. In I. Altman \& S. M. Low (Eds.), Place attachment. New York: Plenum Press. pp. 1-12

Marcheschi, E., Laike, T., Brunt, D., Hansson, L. \& Johansson, M. (2015). Quality of life and place attachment among people with severe mental illness. Journal of Environmental Psychology, 41, 145154.

Martin, T. (1970) Rescuing Fanon from the critics. African Studies Review, 13(3), 381-399. 
McKeown, M., Scholes, A., Jones, F. \& Aindow, W. (2019) Coercive practices in mental health services: stories of recalcitrance, resistance and legitimation. in A. Daley, L. Costa \& P. Beresford (Eds) Madness, violence and power. University of Toronto Press, Toronto.

Mercer, K. (1986) Racism and transcultural psychiatry. In P.Miller and N. Rose (eds) The power of psychiatry. Oxford, Polity Press. pp.112-42.

Moore-Gilbert, B. (1996) Frantz Fanon: En-gendering nationalist discourse. Women: a cultural review, 7(2), 125-135.

Morgan, C., Mallett, R., Hutchinson, G. \& Leff, J. (2004). Negative pathways to psychiatric care and ethnicity: the bridge between social science and psychiatry. Social Science and Medicine, 58, 739752.

NIMHE (2003). Inside outside: improving mental health services for black and minority ethnic communities in England. London: NIMHE.

Penson, W.J. (2014) 'Psy-science and the colonial relationship in the mental health field'. Mental Health Review Journal, 19(3), 176-184.

Proshansky, H. M., Fabian, A. K. \& Kaminoff, R. (1983). Place identity: physical world socialization of the self. Journal of Environmental Psychology, 3, 57-83.

Raleigh, V., Irons, R., Hawe, E., Scobie, S., Cook, A., Reeves, R., Petruckevitch, A. \& Harrison, J. (2007). Ethnic variations in the experiences of mental health service users in England. Results of a national patient survey programme. British Journal of Psychiatry 191, 304-312.

https://doi.org/10.1192/bjp.bp.106.032417

Robertson, M. and Walter, G., 2009. Frantz Fanon and the confluence of psychiatry, politics, ethics and culture. Acta Neuropsychiatrica, 21(6), pp.308-309.

Russo, J. and Beresford, P. (2015) Between exclusion and colonisation: Seeking a place for mad people's knowledge in academia. Disability and Society, 30(1), 153-157.

Sartre, J. P. (1963) Preface. In Fanon, F. (1963) The wretched of the earth. (Trns C. Farrington) New York: Grove Books. pp. 7-31.

Sashidaran, S. P. (1994) Opposing and resisting: a view from the third world. Asylum: the Magazine for Democratic Psychiatry, 8, 1, 31-34.

Sedgwick, P. (1982) Psycho Politics. London: Pluto. 
Sharpley-Whiting, D.T. (1997) Frantz Fanon: Conflicts and Feminisms. Lanham, Maryland: Rowman \& Littlefield Publishers.

Small, S. (1991). Racialised relations in Liverpool: A contemporary anomaly. Journal of Ethnic and Migration Studies, 17(4), 511-537.

Stokols, D. \& Shumaker, S. A. (1982). The psychological context of residential mobility and wellbeing. Journal of Social Issues, 38(3), 149-171.

Stowell-Smith, M. \& McKeown, M. (2001) Race, Stigma and Stereotyping: The Construction of Difference in Forensic Care. In Carlisle, C., Mason, M., Watkins, C. \& Whitehead, E. [Eds] Stigma and Social Exclusion in Healthcare. Routledge, London.

Taaffe, P. \& Mulhearn, T. (1988). Liverpool: a city that dared to fight. London: Fortress.

Thomas, P. (2014) Psychiatry in context: Experience, meaning \& communities. Wyastone Leys, PCCS Books.

Torkington, N.P.K. (1991). The racial politics of health: A Liverpool profile. Merseyside Area Profile Group, Liverpool: University of Liverpool.

Torkington P. (ed) (2009). Their untold stories. Granby Community Mental Health Group: The Windows Project

Von Holdt, K. (2013) The violence of order, orders of violence: Between Fanon and Bourdieu. Current Sociology, 61(2), 112-131.

Wainwright, J. \& McKeown, M. (2019) Place and race - an alternative black mental health service. In L. Sapouna, G. Sidley \& H. Gijbels (eds) Inside out and outside in: alternatives to mainstream mental health services. PCCS Books, Wyastone Leys.

Wainwright, J. \& McKeown, M. \& Kinney, M. (2019) 'In these streets': The saliency of place in an alternative black mental health resource centre. International Journal of Human Rights in Healthcare,

Wallcraft, J. Read, J. \& Sweeny, A. (2003). On our own terms: users and survivors of mental health services working together for support and change. London: The Sainsbury Centre for Mental Health.

Wright S. \& Hutnik N. (2004). Black Spaces Project. London: Mental Health Foundation.

Zak-Williams, A. B. (1997). African diaspora conditioning: The case of Liverpool. Journal of Black Studies, 27(4), 528-542. https://doi.org/10.1177\%2F002193479702700405 
Zeilig, L. (2016). Frantz Fanon: the militant philosopher of third world revolution. Bloomsbury Publishing.

Zubrick, S.R., Dudgeon, P., Gee, G., Glaskin, B., Kelly, K., Paradies, Y., Scrine, C. and Walker, R. (2004) Social determinants of Aboriginal and Torres Strait Islander social and emotional wellbeing. In N. Purdie, P. Dudgeon and R. Walker (eds) Working together: Aboriginal and Torres Strait Islander mental health and wellbeing principles and practice. Commonwealth of Australia, Canberra, Australia, pp.75-90. 
Table 1. Identified themes: MSH members' views

\begin{tabular}{|c|c|}
\hline Theme & Summary \\
\hline Attachment to Liverpool 8 & $\begin{array}{l}\text { Members express affinities for, identification } \\
\text { with, and pride in Liverpool } 8 \text {. This attachment } \\
\text { to place is bound up with local heritage and } \\
\text { ethnicity, including experiences of struggle } \\
\text { against racism in the wider City. }\end{array}$ \\
\hline A Space of Recognition and Belonging & $\begin{array}{l}\text { There is a sense of belonging to a place that is } \\
\text { organically of the local community and situated } \\
\text { in the community. The prevailing social } \\
\text { relations reflect this, and are juxtaposed with } \\
\text { more negative experiences of other services. } \\
\text { There is abundant mutual recognition of shared } \\
\text { aspects of identity across staff-member } \\
\text { boundaries. }\end{array}$ \\
\hline A Safe Haven & $\begin{array}{l}\text { MSH provides a constant source of support and } \\
\text { a safe space of refuge from the troubles and } \\
\text { travails of mental distress and racism. Some } \\
\text { family members and friends can compound } \\
\text { feelings of alienation and stigma. Previous } \\
\text { experiences of disempowerment are } \\
\text { countered. The notion of 'membership' speaks } \\
\text { of equality in relationships, grounded in shared } \\
\text { biography, mutuality, race, place and space. }\end{array}$ \\
\hline Mental distress does not discriminate & $\begin{array}{l}\text { There is common ground amongst peers in the } \\
\text { face of indiscriminate challenges of mental } \\
\text { distress. A sense of community provided within }\end{array}$ \\
\hline
\end{tabular}




\begin{tabular}{|l|l|}
\hline & $\begin{array}{l}\text { the space of MSH is an antidote to personal } \\
\text { difficulties and isolation. }\end{array}$ \\
\hline
\end{tabular}

